\title{
Faktor Dominan pada Indeks Inklusi Perbankan Syariah Sektor Pertanian di Indonesia
}

\author{
Eko Fajar Cahyono
}

Universitas Airlangga Surabaya

email: ekofajarc@feb.unair.ac.id

\author{
M. Faris Fadillah Mardianto \\ Universitas Airlangga Surabaya \\ email: fm.fariz@yahoo.com
}

\author{
Sylva Alif Rusmita \\ Universitas Airlangga Surabaya \\ email: sylvalifr@feb.unair.ac.id
}

\begin{abstract}
The importance of financial inclusion in Islamic Bank is not only affordable for business level, but also agricultural sector. Indonesian Islamic banking as one of the providers of financial services continued to grow, but its market share is still small compared with conventional banking. Therefore financial inclusion Islamic banking, especially in reaching out to the agriculture sector, need to be improved. This study aims to measure the value of financial inclusion Islamic banks in Indonesia province in reaching the agricultural sector, both provincial and district or city. Indexing method factor analysis (Principal Component Analysis) using 14 indicators that have been adapted to the concept of Financial Inclusion Index (FII). Data correlated with Islamic Financial Institution availability can be divided into two factors which are of Islamic banking (including Islamic windows of the conventional bank) and Islamic Rural Bank. The result of the analysis is indicating that the most dominant factor provided by Islamic banking (including Islamic windows of conventional Bank). The result also present the highest index score reached by West Java Province and East Java, while the lowest index score reached by East Nusa Tenggara and West Papua Province.
\end{abstract}

Keywords: financial inclusion; Financial Inclusion Index (FFI); UMKM.

\begin{abstract}
Abstrak: Keuangan inklusi bagi bank syariah sangatlah penting, bukan hanya memberikan pembiayaan pada sektor bisnis namun juga untuk sektor pertanian. Bank syariah di Indonesia sebagai salah satu lembaga keuangan yang terus berkembang memiliki potensi untuk mengembangkan keuangan inklusi walaupun pangsa pasar dari bank syariah masih lebih kecil dibandingkan konvensional. Keberadaan keuangan inklusi di bank syariah khususnya pada sektor pertanian masih perlu ditingkatkan Penelitian ini bertujuan untuk mengukur nilai keuangan inklusi di bank syariah pada sektor
\end{abstract}

Economica: Jurnal Ekonomi Islam - Volume 8, Nomor 1 (2017) 
pertanian di seluruh provinsi yang ada di Indonesia, baik pada level provinsi, kabupaten dan kota. Penelitian ini menggunakan metode index faktor analisis (analisis komponen prinsip) dengan 14 indikator yang diadaptasi dari konsep Indeks Inklusi Keuangan. Data-data berkenaan dengan lembaga keuangan Islam yang tersedia dapat dibagi menjadi dua factor, yaitu faktor yang berkaitan dengan bank syariah (termasuk unit usaha syariah) dan Bank Pembiayaan Rakyat Syariah. Hasil analisis menunjukkan bahwa faktor yang paling dominan adalah faktor yang berkaitan dengan bank syariah dan unit usaha syariah. Hasil menunjukkan bahwa angka indeks tertinggi diraih oleh provinsi Jawa Barat dan Jawa Timur, sedangkan angka indeks terendah diraih oleh provinsi Nusa Tenggara Timur dan Papua Barat.

Kata Kunci: keuangan inklusi; Financial Inclusion Index (FFI); UMKM. 
Faktor Dominan pada Indeks Inklusi Perbankan Syariah...

\section{Pendahuluan}

Inklusi keuangan menjanjikan beberapa hal seperti penurunan ketimpangan pendapatan yang pada gilirannya akan menumbuhkan perekonomian dan mempertinggi GDP serta menurunkan kemiskinan (Kim 2016).

"Financial inclusion holds the promise of boosting growth and reducing poverty and inequality, notably by mobilizing savings and providing households and firms withgreater access to resources needed to finance consumption and investment and to insureagainst shocks. In addition, financial inclusion can foster labour and firm formalization, helping, in turn, boost government revenues and strengthen social safety nets." (Sethy, Developing a Financial Inclusion Index and Inclusive Growth in India 2016).

Masalah kemiskinan di Indonesia adalah sebuah masalah klasik yang masih dihadapi hingga saat ini. Jumlah penduduk miskin Indonesa pada bulan September 2016 adalah kurang lebih 28 juta jiwa yang tersebar di berbagai provinsi di Indonesia (BPS 2016).

Inklusi keuangan adalah indikator penting berorientasi kepada keadilan dan pemerataan. Menurut Islam pemerintah berkewajiban untuk melakukan pemerataan ekonomi dan menghindari kesenjangan pendapatan. Hal ini bermaksud supaya harta itu jangan beredar di antara orang-orang kaya saja sebagaimana firman Allah :

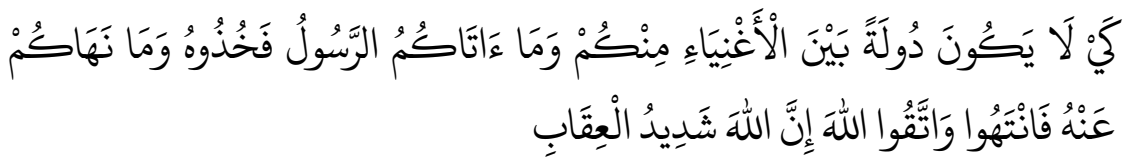

"supaya harta itu jangan hanya beredar di antara orang-orang kaya saja di antara kalian. Apa yang diberikan Rasul kepadamu maka terimalah dia. Dan apa yang dilarangnya bagimu maka tinggalkanlah; dan bertakwalah kepada Allah. Sesungguhnya Allah sangat keras hukumanNya." (QS. al-Hasyr [59]: 7).

Economica: Jurnal Ekonomi Islam - Volume 8, Nomor 1 (2017) 
Keuangan inklusif juga perlu dikaji lebih jauh karena perkembangan sektor perbankan di Indonesia yang pesat. Sejarah bank komersial di Indonesia telah lama bahkan telah dimulai dari berdirinya de Javanese Bank yang merupakan cikal bakal Bank Sentral Indonesia pada masa ini. Menurut statistik perbankan Indonesia yang dikeluarkan oleh Otoritas Jasa Keuangan Republik Indonesia, jumlah kantor bank umum komersil per September 2016 mencapai 32.752 kantor, kemudian jumlah kantor rural bank mencapai 6084 kantor. Pada saat yang sama, jumlah bank di Indonesia mencapai 118 bank dan jumlah rural bank mencapai 1629 buah. Jumlah aset bank komersil umum mencapai 6.455 triliun rupiah dengan jumlah penyaluran dana mencapai 6.315 triliun rupiah dengan jumlah dana pihak ketiga yang terkumpul mencapai 6.084 triliun rupiah (OJK 2016).

Sebagai bangsa dengan jumlah penduduk muslim terbesar di dunia, umat Islam Indonesia memiliki keinginan untuk menjalankan ajaran Islam secara kaffah, sebagaimana difirmankan Allah swt.

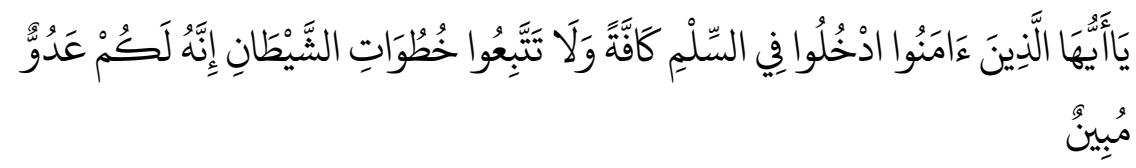

"Hai orang-orang yang beriman, masuklah kalian ke dalam Islam secara keseluruhan, dan janganlah kalian mengikuti langkah-langkah setan. Sesungguhnya setan itu musuh yang nyata bagimu." (QS. al-Baqarah [2]: 208)

Ajaran Islam adalah ajaran yang sempurna dan lengkap meliputi pemenuhan kebutuhan biologis, fisik, psikologis, material dan spiritual, termasuk di dalamnya mengatur masalah bisnis dan ekonomi. Ajaran Islam tentang usaha, misalnya, dapat ditemukan dalam firman Allah swt.:

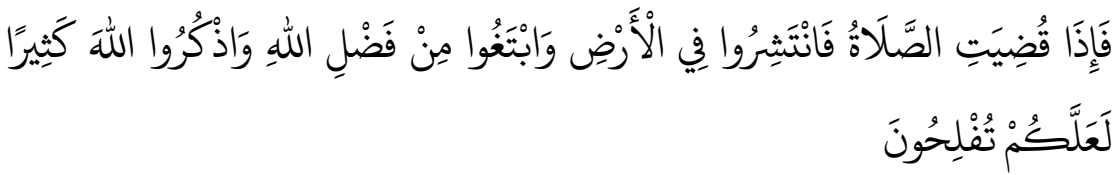


"Apabila telah ditunaikan shalat (Jum'at), maka bertebaranlah kalian di muka bumi, dan carilah karunia Allah dan ingatlah Allah sebanyakbanyaknya supaya kalian beruntung." (QS. al-Jumu'ah [62]: 10)

Perbankan syariah di Indonesia telah berumur seperempat abad, dimulai dari berdirinya Bank Muamalat Indonesia pada tahun 1992. Pada bulan Agustus 2016, jumlah aset milik bank umum syariah di Indonesia tidak kurang dari 216 triliun rupiah. Jumlah kantor bank umum syariah di Indonesia adalah 1776 buah kantor dari 12 bank umum syariah. Sedangkan pada bulan September 2016 aset bank syariah di Indonesia mencapai 64 triliun rupiah dengan jumlah 149 kantor yang merupakan anak usaha dari 22 bank konvensional di Indonesia (OJK 2016).

Berdasarkan kondisi dan fakta yang telah dipaparkan sebelumnya maka seharusnya akses penduduk terhadap lembaga keuangan formal menjadi lebih mudah. Lembaga keuangan formal seharusnya turut berperan dalam pembangunan bangsa pada semua sektor ekonomi. Salah satu yang menjadi sektor yang penting di Indonesia adalah sektor pertanian, karena sektor pertanian telah lama dan secara tradisional menjadi daya topang perekonomian Indonesia.

Pada awal bangsa Indonesia berdiri dan menata diri yaitu pada tahun 1960 kemiskinan yang besar masih melanda bangsa Indonesia dan ketidakmampuan baca dan tulis juga masih membebani bangsa ini. Karena itu pemerintah Indonesia melaksanakan Pembangunan Lima Tahun (PELITA) dimana ada 2 sektor yang menjadi prioritas utama dalam pembangunan nasional, yaitu sector pertanian dan industri. Pertama, karena untuk keamanan pangan, kebutuhan pangan yang paling pokok bagi penduduk Indonesia adalah beras, ketersediaan beras menjadi hal yang vital untuk stabilitas dan keamanan nasional. Kedua, bahwa sektor pertanian telah dan masih menjadi sektor yang mempekerjakan sebagian besar penduduk Indonesia. Pada tahun 2003, 60 persen pekerja di seluruh negeri bekerja pada sektor ini. Ketiga, bahwa pertumbuhan sektor ini akan 
berdampak pada penurunan kemiskinan secara signifikan yaitu melalui kebijakan pemerintah yang bersifat khusus seperti insentif untuk pekerja kurang ahli dan penyediaan akses pendidikan dasar dan kesehatan dasar di pedesaan (Tambunan 2007).

Salah satu provinsi yang memberikan pengertian tentang pentingnya sektor pertanian adalah provinsi Jawa Timur dimana mata pencaharian terbesar di Jawa Timur adalah pertanian. Hal ini sesuai dengan pemanfaatan lahan di Jawa Timur yang tiga perempatnya dimanfaatkan untuk pertanian. Hampir setengah dari tenaga kerja di Jawa Timur bergantung pada sektor pertanian, dari 46 persen di tahun 2006 hingga 44 persen di tahun 2010 dengan jumlah tenaga kerja sekitar 8 juta jiwa. Ini juga mencakup kegiatan agrobisnis berbasis tanaman pangan, hortikultura, perkebunan, perikanan dan kehutanan. Oleh sebab itu, arah kebijakan pertanian di Jawa Timur mengarah pada pengembangan agrobisnis yang tidak hanya mengandalkan pemanfaatan sumber daya alam yang ada sebagai keunggulan komparatifnya, tapi juga secara bertahap akan terus dikembangkan sektor pertanian yang lainya (Jatim 2011).

Daerah dengan sektor pertanian sebagai basis ekonominya memiliki kecenderungan tingkat kemiskinannya tinggi. Sampang, Sumenep dan Pamekasan, misalnya, adalah kabupaten di Provinsi Jawa Timur dengan basis pertanian yang memiliki jumlah penduduk miskin terbesar. Di sini, Location Quotient (LQ) digunakan sebagai indikator basis aktivitas ekonomi. Jika suatu daerah dengan nilai LQ untuk pertanian lebih besar dari satu, maka daerah tersebut dapat dikategorikan sebagai daerah yang aktivitas ekonominya berbasis pada sektor pertanian. Daerah perkotaan umumnya basis aktivitas ekonominya bukan di sektor pertanian. Penduduk miskin ternyata banyak terdapat di daerah yang basis ekonominya pertanian (Jatim 2011).

Sementara itu, perbankan syariah di Indonesia, sebagai salah satu lembaga penyedia layanan pembiayaan, terus mengalami pertumbuhan dari 
waktu ke waktu yang dapat dilihat dari semakin banyaknya bank syariah di Indonesia. Kondisi ini membuktikan bahwa perbankan syariah di Indonesia melihat sisi positif penerapan sistem bagi hasil (muḍārabah) dan penyertaan modal (mushārakah) yang dilakukan oleh bank syariah yang diatur dalam UU Nomor 10 tahun 1998 pasal 1 ayat 13. Selain itu, perbankan syariah juga diakui kekuatannya (robustness) dalam tatanan perekonomian. Sistem perbankan syariah ini bahkan dianggap lebih tangguh dalam menghadapi ketidakstabilan perekonomian global, karena sistem ini bebas dari unsur derivatif dan produk spekulatif. Meskipun demikian, market share perbankan syariah di Indonesia ini masih kecil dibandingkan dengan perbankan konvensional. Perbankan syariah ini masih tergolong baru di Indonesia. Oleh karena itu, informasi seputar perbankan syariah ini harus terus digaungkan. Perbankan syariah hendaknya juga memberikan inovasi tepat guna dan tepat sasaran yang sesuai kebutuhan masyarakat, serta mempermudah akses kepada siapa saja agar mudah dijangkau oleh seluruh masyarakat Indonesia. Mengingat Indonesia merupakan salah satu negara dengan mayoritas penduduk Muslim di dunia, sudah selayaknya perbankan syariah ini menjadi pelopor lembaga keuangan di Indonesia.

Salah satu masalah yang dihadapi oleh para petani adalah kurangnya akses mereka terhadap lembaga keuangan formal. Petani memerlukan tambahan modal untuk meningkatkan hasil produksi mereka. Perbankan syariah merupakan lembaga keuangan yang mempunyai kedekatan dengan sektor riil, utamanya pertanian. Namun demikian pembiayaan terhadap sektor ini masih sangat kecil. Penyebab utama dari hal itu adalah sektor pertanian memiliki risiko yang sangat tinggi.

Berdasarkan latar belakang di atas, penelitian ini akan meneliti faktor yang paling dominan dalam kerangka pengukuran indeks keuangan inklusif perbankan syariah di Indonesia pada sektor pertanian. Tujuan penelitian ini adalah untuk menyelidiki faktor paling dominan dalam kerangka 
pengukuran indeks keuangan inklusif perbankan syariah di Indonesia pada sektor pertanian.

\section{Landasan Teori}

Inklusi keuangan adalah suatu hal yang krusial dalam pembangunan ekonomi modern. Beberapa peneliti mendefinisikan inklusi keuangan sebagai kebalikan dari eksklusi keuangan. Sarma (Sarma 2012) mendefinisikan inklusi keuangan sebagai sebuah proses yang menjamin kemudahan dalam akses, ketersediaan, dan manfaat dari sistem keuangan formal bagi seluruh pelaku ekonomi. Menurut Bank Indonesia (Indonesia 2014) inklusi keuangan merupakan seluruh upaya untuk meningkatkan akses masyarakat terhadap jasa-jasa keuangan dengan cara menghilangkan segala bentuk hambatan baik yang bersifat harga maupun non harga.

Tujuan inklusi keuangan adalah agar semua orang mendapatkan akses yang adil dan sama untuk menjangkau lembaga keuangan formal. Perlakuan adil ini tidak memandang asal daerah, perkotaan atau pedesaan, jenis kelamin, ras, suku bangsa dan agama, seperti yang disebutkan oleh Bindu dan Jain (Sneha 2011):

"The correlation between financial inclusion and economic growth has long been widely recognized: low financial inclusion impedes economic growth. Access toeasy and affordable credit by the disadvantaged social groups is acknowledged as a key criterion for poverty alleviation and reducing social inequity. However despite broad consensus on the importance of access to finance as a powerfulpoverty alleviation tool and substantial financial sector reforms in India, it isestimated nearly half the rural households continue to be excluded from the formal financial sector."

Ada beberapa penelitian yang telah dilakukan sebelumnya terkait dengan penelitian ini. Penelitian yang dilakukan oleh Nasution, Sari dan Dwilita (Lia Nazliana Nasution 2013), yang menyelidiki tentang faktor faktor pendukung kebijakan inklusi keuangan di provinsi Sumatera Utara. Variabel 
yang diteliti meliputi jumlah penduduk, jumlah angkatan kerja produktif, jumlah produk domestik regional bruto Sumatera Utara, dan jumlah kantor cabang bank di Sumatera Utara. Hasilnya menunjukkan bahwa faktor-faktor tersebut dianggap sudah layak dan turut mendukung penerapan keuangan inklusi di Sumatera Utara terutama faktor produk domestik regional bruto dan faktor jumlah kantor cabang bank mengalami pertumbuhan yang baik.

Penelitian yang dilakukan oleh Sethy (Sethy, Developing a Financial Inclusion Index and Inclusive Growth in India 2016) yang mengukur indeks keuangan inklusif di India dengan aspek yang multidimensi. Studi yang dilakukan tahun 2011 sampai tahun 2012 ini berkesimpulan bahwa India masuk dalam kategori indeks keuangan inkusif yang baik. Penelitian ini menggunakan data penetrasi bank (banking penetration), keterjangkauan layanan perbankan (availability of banking services), serta penggunaan sistem perbankan (usage of the banking system). Penelitian ini juga mengungkap bahwa, pada periode 1998-2009 India dalam keadaan keuangan inklusif yang rendah dengan menggunakan data dari supply side dimensions, seperti akses untuk menabung (access to saving), akses untuk berasuransi (access to insurance), dan risiko bank (bank risk).

Pada distrik Ardha Pradesh India, Bindu dan Jain (Sneha 2011), melakukan penelitian dan menemukan fakta bahwa bank memiliki peran untuk meningkatkan tingkat inklusi keuangan petani dan masyarakat pedesaan. Peningkatan inklusi keuangan dapat terjadi karena peran bank formal dalam memberikan literasi keuangan dan konsultasi keuangan kepada para petani di desa.

Studi inklusi keuangan juga dilakukan oleh Aysan Dolhun dan Turhan (Ahmet Faruk Aysan 2013), yang mengungkap adanya hubungan yang erat antara tingkat partisipasi bank dengan tingkat inklusi keuangan di Turki. Penelitian ini menggunakan data-data seluruh bank termasuk bank konvensional dan bank Islam. Studi ini juga mengungkap bagaimana deregulasi memengaruhi tingkat partisipasi bank di Turki serta adanya 
sukuk yang mampu memengaruhi tingkat partisipasi mengakses lembaga keuangan di Turki.

Davutyan dan Öztürkkal (Öztürkkal 2016) meneliti tentang keputusan orang untuk menabung dan meminjam pada bank di negara berpendapatan sedang dan tinggi. Aktivitas menabung dan meminjam erat kaitanya dengan inklusi keuangan. Faktor-faktor yang memengaruhi keputusan menabung dan meminjam adalah pendapatan (income), pendidikan (education), status pernikahan (marital status), serta wilayah (region). Kemudian, ada juga pengaruh variabel lainnya terhadap keputusan menabung dan meminjam, seperti status perpindahan dari desa ke kota (rural to urban migrant status) dan keyakinan agama.

Inklusi keuangan juga terkait dengan akses kredit pada people business credit program (KUR) di Indonesia (Fara Farida 2015). Penelitian ini menjelaskan bahwa determinan KUR di antaranya adalah gender, lama bisnis, kendala bisnis, kepemilikan rekening bank, pasangan kerja, serta sumber pinjaman lainnya. Berdasarkan beberapa variabel tersebut, secara gender, lelaki memiliki tingkat kemungkinan 6,56 lebih besar dibanding perempuan dalam hal terbukanya kesempatan mengakses KUR; masyarakat yang memiliki rekening bank, berpeluang 3,66 kali lebih besar untuk memperoleh kredit; sedangkan para pengusaha baru yang mengalami kendala modal dan masyarakat yang memiliki pasangan sudah bekerja juga berpotensi untuk mengakses KUR.

\section{Metode Penelitian}

\section{Ruang Lingkup Penelitian dan Metode Pengumpulan Data}

Ruang lingkup penelitian ini mencakup seluruh provinsi di Indonesia, di mana data yang digunakan merupakan data sekunder yang diperoleh dari website Otoritas Jasa Keuangan (www.ojk.go.id) serta data sekunder yang berasal dari dokumen resmi Otoritas Jasa Keuangan Republik Indonesia 
yaitu Statistik Perbankan Syariah Indonesia 2016. Data yang digunakan antara lain disajikan dalam tabel 1 berikut ini:

Tabel 1. Variabel-variabel Penelitian

\begin{tabular}{ll}
\hline $\begin{array}{l}\text { Lambang } \\
\text { Variabel }\end{array}$ & Nama Variabel \\
\hline X1 & $\begin{array}{l}\text { Jumlah Aset pada Bank Umum Syariah (BUS) dan Unit Usaha } \\
\text { Syariah (UUS) }\end{array}$ \\
X2 & Jumlah Aset pada Bank Pembiayaan Rakyat Syariah (BPRS) \\
X3 & Jumlah Dana Pihak Ketiga (DPK) pada Bank Umum Syariah \\
& (BUS) dan Unit Usaha Syariah \\
X4 & Jumlah Dana Pihak Ketiga (DPK) pada Bank Pembiayaan Rakyat \\
& Syariah (BPRS) \\
X5 & Jumlah Dana yang Disalurkan Pembiayaan BPRS pada Bidang \\
& Pertanian \\
X6 & Jumlah Dana yang Disalurkan BUS dan UUS untuk Pertanian \\
X7 & Jumlah Dana yang Disalurkan BUS dan UUS untuk Perikanan \\
X8 & Jumlah Kantor Bank Umum Syariah (BUS) \\
X9 & Jumlah Kantor Unit Usaha Syariah (UUS) \\
X10 & Jumlah Dana untuk Modal Kerja dari Bank Umum Syariah (BUS) \\
X11 & Jumlah Dana untuk Investasi dari Bank Umum Syariah (BUS) \\
X12 & Jumlah Bank Pembiayaan Rakyat Syariah (BPRS) \\
X13 & Jumlah Dana untuk Modal Kerja dari Bank Pembiayaan Rakyat \\
& Syariah (BPRS) \\
X14 & Jumlah Dana untuk Investasi dari Bank Pembiayaan Rakyat \\
& Syariah (BPRS) \\
\hline
\end{tabular}

\section{Metode Analisis}

Metode analisis yang digunakan dalam penelitian ini merujuk kepada penelitian yang dilakukan oleh Daroini dan Farihah (Farihah 2015) yang terdiri dari analisis deskriptif dan juga analisis inferensia. Analisis deskriptif merupakan analisis untuk memberikan gambaran informasi dengan menyajikan tabel-tabel, diagram diagram informasi. Sedangkan analisis 
inferensia digunakan untuk menyusun indeks finansial inklusif pada perbankan syariah. Penelitian Daroini dan Farihah (Farihah 2015) menggunakan analisis faktor untuk menentukan faktor dominan dalam angka indeks inklusi keuangan perbankan syariah pada sektor usaha kecil menengah di Indonesia. Penyususan angka indeks dalam penelitian ini merujuk pada Handbook on Constructing Composite Indicator 2008 oleh Organization for Economic Coperation and Development (OECD).

\section{Standarisasi dan Pembentukan Angka Indeks}

Untuk melakukan penyusunan indeks, langkah selanjutnya adalah proses standarisasi dengan metode z score yang dapat menyebabkan skor faktor dan juga skor komposit akhir yang dihasilkan bertanda positif, nol atau negative. Untuk memudahkan interpretasi, maka dilakukan transformasi agar diperoleh angka indeks rentang nilai 0 sampai 100. Metode transformasi yang digunakan adalah min max. Berdasarkan nilai indeks tersebut, dilakukan pemetaan dengan menggunakan ArcMap 10.

\section{Pengujian Data Awal}

Dalam pengujian data awal dilakukan pengujian-pengujian sebagaimana terlihat pada tabel 2

Tabel 2. KMO and Bartlett's Test

\begin{tabular}{rlr}
\hline Kaiser-Meyer-Olkin Measure of Sampling Adequacy. & .824 \\
& Approx. Chi-Square & 1333.452 \\
Bartlett's Test of Sphericity & df & 91 \\
& Sig. & .000 \\
\hline
\end{tabular}


Faktor Dominan pada Indeks Inklusi Perbankan Syariah...

\section{Uji Korelasi Antar Variabel}

Untuk mengetahui apakah analisis faktor layak digunakan dalam penelitian ini, maka harus dilakukan pengujian kebebasan antar variabel. Adapun pengujian yang sesuai adalah uji Bartlett Sphericity.

Hipotesis:

$H_{0}$ : Antar variabel tidak saling berkorelasi

$H_{1}$ : Antar variabel saling berkorelasi

Statistik Uji:

$$
\begin{aligned}
\chi_{\text {hitung }}^{2} & =1333.452 \\
\chi_{\text {tabel }}^{2} & =\chi_{\mathbf{0 . 0 5}, \mathbf{1} \frac{\mathbf{1}}{\mathbf{1 4}}(\mathbf{1 4}-\mathbf{1})}^{2} \\
& =\chi_{\mathbf{0 . 0 5 , 9 1}}^{2} \\
& =114.2678677
\end{aligned}
$$

Kriteria Uji :

Oleh karena $\chi_{\text {hitung }}^{2} \geq \chi_{\text {tabel }}^{2}$, artinya antar variabel saling berkorelasi. Hubungan antar variabel yang saling berkorelasi telah dipenuhi sehingga dapat dilanjutkan ketahapan berikutnya.

\section{Uji Kecukupan Data Kaiser Meyer Olkin (KMO)}

Untuk mengetahui apakah semua data yang telah terambil telah cukup untuk difaktorkan, maka harus dilakukan pengujian kecukupan data. Adapun pengujian yang sesuai adalah uji KMO.

Hipotesis :

$H_{0}$ : Jumlah data cukup untuk difaktorkan

$H_{1}$ : Jumlah data tidak cukup untuk difaktorkan

Diperoleh KMO $=0,824>0,5$ sehingga $H_{0}$ gagal ditolak yang berarti jumlah data telah cukup untuk difaktorkan. Dengan kata lain bahwa variabel dan sampel yang digunakan memungkinkan untuk dilakukan analisis lebih lanjut.

Economica: Jurnal Ekonomi Islam - Volume 8, Nomor 1 (2017) 


\section{Uji Normalitas}

Selain variabel yang saling berkorelasi dan saling bebas, hal lain yang harus dipenuhi sebelum melakukan analisis faktor adalah menguji apakah variabel berdistribusi normal multivariat.

Hipotesis:

$H_{0}$ : Data berdistribusi normal multivariat

$H_{1}$ : Data tidak berdistribusi normal multivariat

Statistik Uji :

$d_{i}^{2}=\left(\boldsymbol{x}_{i}-\overline{\boldsymbol{x}}\right)^{T} \mathbf{S}^{-1}\left(\boldsymbol{x}_{i}-\overline{\boldsymbol{x}}\right) \quad ; i=1,2, \ldots, n$

Berdasarkan hasil perbandingan $d_{i}^{2}$ dengan $\chi_{\text {tabel }}^{2}$ diperoleh kondisi terdapat $54.5455 \%>50 \%$ dari 33 pengamatan dengan kondisi $d_{i}^{2}<\chi_{\text {tabel }}^{2}$, artinya $H_{0}$ gagal ditolak sehingga data dikatakan berdistribusi normal.

\section{Melakukan Analisis Faktor}

Dalam langkah ini dilakukan analisis faktor untuk mengidentifikasi variabel berdasarkan kemiripannya. Kemiripan tersebut ditunjukkan dengan nilai korelasi yang tinggi. Variabel-variabel yang memiliki korelasi yang tinggi akan membentuk satu kerumunan faktor. Prinsip dasar dalam analisis faktor adalah menyederhanakan deskripsi tentang data dengan mengurangi jumlah variabel atau dimensi. Langkah-langkahnya adalah sebagai berikut :

1. Menentukan Measure of Sampling Adequacy (MSA).

Measure of Sampling Adequacy (MSA) digunakan untuk mengetahui apakah variabel sudah memadai untuk dianalisis lebih lanjut. Jika nilai MSA lebih besar dari 0,5 maka variabel tersebut sudah memadai untuk dianalisis lebih lanjut. Apabila terdapat nilai MSA dari variabel-variabel awal yang kurang dari 0,5 harus dikeluarkan satu per satu dari analisis, dan mengeluarkan nilai MSA yang paling kecil jika nilai MSA yang dibawah 0.5 sudah habis sampai pembentukan faktor yang sesuai terbentuk, dengan 
diurutkan dari variabel yang nilai MSAnya terkecil dan tidak digunakan lagi dalam analisis selanjutnya.

Tabel 3 menunjukkan seberapa besar sebuah variabel dapat menjelaskan faktor. Misal X1 nilainya 0.994, artinya variabel X1 dapat menjelaskan faktor sebesar 99.4\%. Begitu pula dengan variabel lainnya, di mana semuanya $>50 \%$, oleh karenanya dapat disimpulkan bahwa semua variabel dapat menjelaskan faktor, dan tidak perlu mengeliminir variabel.

2. Penentuan Jumlah Faktor

Jumlah faktor yang akan dibentuk ditentukan dengan melakukan kombinasi beberapa kriteria untuk mendapatkan jumlah faktor yang paling sesuai dengan data penelitian melalui Tabel Total Variance Explained di bawah ini berguna untuk menentukan berapakah faktor yang mungkin dapat dibentuk.

Tabel 3. Total Variance Explained

\begin{tabular}{|c|c|c|c|c|c|c|c|c|c|}
\hline \multirow{2}{*}{$\begin{array}{l}\text { Co } \\
\text { mp } \\
\text { one } \\
\text { nt }\end{array}$} & \multicolumn{3}{|c|}{ Initial Eigenvalues } & \multicolumn{3}{|c|}{$\begin{array}{l}\text { Extraction Sums of Squared } \\
\text { Loadings }\end{array}$} & \multicolumn{3}{|c|}{$\begin{array}{l}\text { Rotation Sums of Squared } \\
\text { Loadings }\end{array}$} \\
\hline & Total & $\begin{array}{c}\% \text { of } \\
\text { Variance }\end{array}$ & $\begin{array}{l}\text { Cumula } \\
\text { tive \% }\end{array}$ & Total & $\begin{array}{c}\% \text { of } \\
\text { Variance }\end{array}$ & $\begin{array}{l}\text { Cumula } \\
\text { tive } \%\end{array}$ & Total & $\begin{array}{c}\% \text { of } \\
\text { Variance }\end{array}$ & $\begin{array}{l}\text { Cumula } \\
\text { tive } \%\end{array}$ \\
\hline 1 & 8.340 & 59.570 & 59.570 & 8.340 & 59.570 & 59.570 & 7.498 & 53.557 & 53.557 \\
\hline 2 & 4.436 & 31.684 & 91.254 & 4.436 & 31.684 & 91.254 & 5.278 & 37.697 & 91.254 \\
\hline 3 & .676 & 4.826 & 96.080 & & & & & & \\
\hline 4 & .226 & 1.617 & 97.697 & & & & & & \\
\hline 5 & .138 & .985 & 98.682 & & & & & & \\
\hline 6 & .106 & .755 & 99.437 & & & & & & \\
\hline 7 & .035 & .247 & 99.684 & & & & & & \\
\hline 8 & .025 & .180 & 99.865 & & & & & & \\
\hline 9 & .012 & .085 & 99.950 & & & & & & \\
\hline 10 & .004 & .027 & 99.976 & & & & & & \\
\hline 11 & .002 & .018 & 99.994 & & & & & & \\
\hline 12 & .000 & .003 & 99.997 & & & & & & \\
\hline 13 & .000 & .002 & 99.999 & & & & & & \\
\hline 14 & .000 & .001 & 100.000 & & & & & & \\
\hline
\end{tabular}

Extraction Method: Principal Component Analysis.

Economica: Jurnal Ekonomi Islam - Volume 8, Nomor 1 (2017)

http://journal.walisongo.ac.id/index.php/economica 
Kriteria pertama yang digunakan adalah nilai eigen. Faktor yang mempunyai nilai eigen lebih dari 1 akan dipertahankan dan faktor yang mempunyai nilai eigen kurang dari 1 tidak akan diikutsertakan dalam model. Dari tabel di atas diperoleh nilai eigen yang lebih besar dari 1 pada 1 faktor dan 2 faktor. Dengan kriteria ini, diperoleh jumlah faktor yang digunakan adalah 2 faktor. Kriteria kedua adalah penentuan berdasarkan nilai persentase variansi total yang dapat dijelaskan oleh banyaknya faktor yang akan dibentuk. Dari tabel di atas dapat dilakukan interpretasi yang berkaitan dengan variansi total kumulatif sampel. Jika variabel-variabel itu diringkas menjadi beberapa faktor, maka nilai total variansi yang dapat dijelaskan adalah sebagai berikut.

a. Jika ke-14 variabel diekstraksi menjadi 1 faktor, diperoleh variansi total yang dapat dijelaskan adalah 8.340/14 x 100\%=59.570\%.

b. Jika ke-14 variabel diekstraksi menjadi 2 faktor, diperoleh variansi total yang dapat dijelaskan adalah 4.436/14 x 100\% = 31.684\%, dan variansi total kumulatif untuk 2 faktor adalah 59.570\% $+31.684 \%=91,254 \%$

Dengan mengekstraksi variabel-variabel awal menjadi 2 faktor telah dihasilkan variansi total kumulatif yang besar yaitu 91,254\%, artinya dari 2 faktor yang terbentuk sudah dapat mewakili 14 variabel. Dengan demikian ekstraksi 2 faktor yang diperoleh telah dapat dihentikan dan telah memenuhi kriteria kedua.

Kriteria ketiga adalah penentuan berdasarkan scree plot. Scree plot merupakan suatu plot nilai eigen terhadap jumlah faktor yang diekstraksi. Titik pada tempat di mana scree mulai terjadi menunjukan banyaknya faktor yang tepat. Titik ini terjadi ketika scree mulai terlihat mendatar. Pada Gambar 1 berikut diketahui bahwa scree plot mulai mendatar pada ekstraksi variabel-variabel awal menjadi 2 faktor. Dari kombinasi ketiga kriteria tersebut dapat disimpulkan bahwa ekstraksi faktor yang paling tepat adalah 2 faktor. 
Faktor Dominan pada Indeks Inklusi Perbankan Syariah...

\section{Penentuan Anggota Faktor}

Setelah diketahui bahwa faktor maksimal yang bisa terbentuk adalah 2 faktor, selanjutnya dilakukan penentuan masing-masing variabel akan masuk ke dalam faktor mana, apakah faktor 1, atau faktor 2. Cara menentukan tersebut adalah dengan melihat tabel 4 Rotated Component Matrix seperti di bawah ini :

Tabel 4. Rotated Component Matrix ${ }^{\mathrm{a}}$

\begin{tabular}{lll}
\hline & \multicolumn{3}{c}{ Component } \\
\hline X1 & \multicolumn{2}{c}{} \\
X11 & .995 & .065 \\
X7 & .994 & .085 \\
X3 & .993 & .032 \\
X6 & .991 & .116 \\
X10 & .980 & -.092 \\
X8 & .972 & .214 \\
X9 & .727 & .666 \\
X2 & .653 & .489 \\
X4 & .054 & .987 \\
X13 & .207 & .977 \\
X12 & .023 & .932 \\
X14 & .062 & .903 \\
X5 & .053 & .903 \\
\hline
\end{tabular}

Extraction Method: Principal Component Analysis.

Rotation Method: Varimax with Kaiser Normalization.

a. Rotation converged in 3 iterations.

Berdasarkan tabel di atas maka dapat diperoleh anggota Faktor 1 dan Faktor 2.

Faktor 1 : X1, X11, X7, X3, X6, X10, X8, X9

Faktor 2 : X2, X4, X13, X12, X14, X5

Economica: Jurnal Ekonomi Islam - Volume 8, Nomor 1 (2017)

http://journal.walisongo.ac.id/index.php/economica 
Faktor 1 merupakan faktor yang terkait dengan Bank Umum Syariah (BUS) dan Unit Usaha Syariah (UUS).

Faktor 2 merupakan faktor yang terkait dengan Bank Pembiayaan Rakyat Syariah (BPRS)

Setelah diketahui bahwa 2 faktor adalah jumlah yang paling optimal, maka tabel component matrix menunjukkan distribusi 14 variabel tersebut pada dua faktor yang terbentuk.

Tabel 5. Component Transformation Matrix

\begin{tabular}{lcc}
\hline Component & \multicolumn{2}{c}{$\mathbf{2}$} \\
\hline 1 & .886 & .464 \\
2 & -.464 & .886 \\
\hline Extraction Method : Principal Component Analysis. \\
Rotation Method : Varimax with Kaiser & \\
Normalization. & &
\end{tabular}

Tabel 5 di atas menunjukkan bahwa pada component 1 nilai korelasi $0,886>0,5$, component 2 juga sama yaitu $0,866>0,5$. Karena semua component $>0,5$ maka kedua faktor yang terbentuk dapat dikatakan tepat dalam merangkum keempat belas variabel yang ada.

\section{Penentuan Faktor Dominan}

Setelah terbentuk faktor yang masing-masing beranggotakan variabelvariabel yang diteliti, maka dilakukan penentuan faktor dominan. Berdasarkan hasil explained variances yang terbesar, maka faktor yang terkait dengan Bank Umum Syariah (BUS) dan Unit Usaha Syariah (UUS) adalah faktor dominan atau faktor yang paling berkontribusi dalam pengukuran financial inclusion perbankan syariah pada sektor pertanian di Indonesia. 
Faktor Dominan pada Indeks Inklusi Perbankan Syariah...

\section{Hasil dan Pembahasan}

Dalam tabel 6 berikut ini dapat dilihat hasil olahan perangkat lunak SPSS berkenaan dengan analisis faktor indeks inklusi keuangan syariah di Indonesia.

Tabel 6. Statistik Deskriptif

\begin{tabular}{lrlr}
\hline Faktor & Nilai Tertinggi & Provinsi & \multicolumn{1}{c}{ Rata rata } \\
\hline X1 & 233386 & Jakarta & 12535.76 \\
X2 & 2072192 & West Java & 207610.15 \\
X3 & 124263 & Jakarta & 7383.61 \\
X4 & 92954 & Jakarta & 6680.00 \\
X5 & 124043 & West Java & 11189.45 \\
X6 & 4084 & Jakarta & 234.76 \\
X7 & 794 & Jakarta & 39.27 \\
X8 & 311 & West Java & 53.79 \\
X9 & 41 & East Java & 9.94 \\
X10 & 29507 & Jakarta & 1928.64 \\
X11 & 21280 & Jakarta & 1224.73 \\
X12 & 29 & West Java & 5.00 \\
X13 & 623910 & West Java & 83300.61 \\
X14 & 663002.00 & West Java & 38103.69 \\
Valid N & & & 70 \\
(listwise) & & & \\
\hline
\end{tabular}

Hasil dalam tabel di atas menunjukkan provinsi dengan indeks inklusi keuangan syariah tertinggi di Indonesia. Pada tabel 6 diperlihatkan keempat belas faktor yang diteliti dan digunakan sangat memengaruhi indeks keuangan inklusif lembaga keuangan syariah. Pada tabel 6 pula diperlihatkan rangking tertinggi bagaimana masing-masing faktor yang diteliti paling

Economica: Jurnal Ekonomi Islam - Volume 8, Nomor 1 (2017) 
memengaruhi indeks inklusi perbankan syariah pada sektor pertanian di Indonesia, ternyata terlihat bahwa faktor-faktor terteliti sangat memengaruhi inklusivitas keuangan syariah pada provinsi-provinsi di pulau Jawa, seperti DKI Jakarta, Jawa Barat, dan Jawa Timur. Tidak dapat dipungkiri karena pulau Jawa adalah letak dari pusat atau ibukota negara sekaligus sebagai pusat bisnis dan perdagangan, maka pulau Jawa memiliki infrastruktur yang lebih lengkap dan lebih banyak dibanding dengan pulaupulau lain di Indonesia. Dengan infrastruktur yang lebih lengkap, maka akses masyarakat terhadap lembaga keuangan formal di pulau Jawa juga lebih tinggi. Selain itu, karena populasi penduduk di pulau Jawa merupakan yang terbesar dan terpadat di Indonesia, jumlah permintaan terhadap jasa keuangan pun menjadi tinggi. Sedangkan hasil indeks keuangan inklusif keuangan Islam pada sektor pertanian di seluruh Indonesia dapat dilihat pada tabel 7 berikut ini.

Tabel 7. Indeks Kontribusi Daerah untuk Pengukuran Financial Inclusion Perbankan Syariah pada Sub Sektor Pertanian di Indonesia

\begin{tabular}{lll}
\hline No & Provinsi & Indeks \\
\hline 1 & Nanggroe Aceh Darussalam & 1.91 \\
2 & North Sumatera & 1.39 \\
3 & West Sumatera & 2.59 \\
4 & South Sumatera & 0.29 \\
5 & Bangka Belitung & 6.76 \\
6 & Jambi & 0.05 \\
7 & Bengkulu & 2.19 \\
8 & Riau & 1.48 \\
9 & Riau Islands & 0.57 \\
10 & Lampung & 3.49 \\
11 & Jakarta & 4.34 \\
12 & West Java & 29.42 \\
13 & Banten & 9.9 \\
14 & Central Java & 9.91
\end{tabular}


Faktor Dominan pada Indeks Inklusi Perbankan Syariah...

\begin{tabular}{lll}
\hline No & Provinsi & Indeks \\
\hline 15 & Yogyakarta & 4.54 \\
16 & East Java & 15.56 \\
17 & Bali & 0.13 \\
18 & West Kalimantan & 0.1 \\
19 & Central Kalimantan & 0.14 \\
20 & East Kalimantan & 0.19 \\
21 & South Kalimantan & 0.51 \\
22 & North Sulawesi & 0.01 \\
23 & Gorontalo & 0.01 \\
24 & West Sulawesi & 0.01 \\
25 & Central Sulawesi & 0.03 \\
26 & South East Sulawesi & 0.02 \\
27 & South Sulawesi & 1.61 \\
28 & Maluku & 0.01 \\
29 & North Maluku & 0.25 \\
30 & West Nusa Tenggara & 2.53 \\
31 & East Nusa Tenggara & 0 \\
32 & West Papua & 0.01 \\
33 & Papua & 0.03 \\
\hline & & \\
\hline
\end{tabular}

Tabel 7 di atas menunjukkan bahwa secara umum angka kontribusi kawasan barat Indonesia terhadap indeks keuangan syariah inklusi pembiayaan sektor pertanian paling dominan. Kontributor terhadap indeks inklusi keuangan syariah sektor pertanian secara keseluruhan utamanya adalah provinsi-provinsi di pulau Jawa, seperti DKI Jakarta sebesar 4,34; Jawa Barat sebesar 29,42; Banten 9,9; Yogyakarta 4,54; Jawa Tengah 9,91; Jawa Timur 15,56. Di Indonesia bagian barat yang paling mendominasi adalah provinsi Jawa Barat dengan nilai 29,42; diikuti oleh provinsi Jawa Timur dengan indeks 15,56. Hal ini dikarenakan perkembangan pangsa pasar Bank Syariah dan Unit Usahanya masih didominasi oleh kedua

Economica: Jurnal Ekonomi Islam - Volume 8, Nomor 1 (2017) http://journal.walisongo.ac.id/index.php/economica 
provinsi tersebut, berdasarkan kantor cabang, jumlah aset, dana pihak ketiga dan pembiayaan di daerah Jawa Barat dan Jawa Timur.

Kemudian, kawasan di luar Jawa memiliki angka kontribusi sedang, yang diikuti oleh provinsi-provinsi di pulau Sumatera seperti Bangka Belitung sebesar 6,76; Lampung 3,49, Bengkulu 2,16; dan Sumatera Barat 2,59. Menurut Mulya Siregar (Siregar 2002), perkembangan perbankan syariah di Indonesia akan dipengaruhi oleh kebutuhan atau permintaan masyarakat terhadap layanan jasa perbankan syariah (demand side).

Dalam sebuah penelitian yang dilakukan oleh Siregar (2002), untuk mengetahui kondisi sisi permintaan tersebut telah dilakukan penelitian "Potensi, Preferensi, dan Perilaku Masyarakat terhadap Bank Syariah" di pulau Jawa (tidak termasuk DKI Jaya), Sumatera Barat, dan Jambi. Hasil penelitian menunjukkan, 45\% dari responden berpendapat bahwa sistem bunga tidak sejalan dengan ajaran agama yang dianut. Hal ini dijadikan patokan untuk menentukan wawasan masyarakat terhadap bank syariah. Angka-angka tersebut juga dapat digunakan sebagai salah satu ukuran bagi potensi minat masyarakat terhadap layanan bank syariah. Harus disadari, jumlah tersebut dapat naik atau turun, tergantung pada kinerja perbankan syariah, seperti kualitas pelayanan dan tingkat profitabilitas. Selain itu, keberhasilan bank syariah dalam mempromosikan sistem ini kepada semua lapisan masyarakat sangat menentukan minat masyarakat untuk bermitra dengan bank syariah.

Selanjutnya, angka kontribusi terendah dimiliki oleh provinsi Nusa Tenggara Timur sebesar 0, kemudian Papua Barat sebesar 0,01, dan Papua sebesar 0,03. Hal ini disebabkan oleh ketersediaan infrastruktur yang rendah yang berdampak pada akses terhadap lembaga keuangan formal menjadi rendah dan wawasan tingkat pendidikan yang masih di bawah provinsi lain.

Hasil penelitian Sanjaya dan Nursechafia (Nursechafia 2016) menyebutkan bahwa indeks keuangan inklusif di Indonesia memiliki hasil 
yang bervariasi menurut provinsi. Provinsi yang berada di Timur Indonesia secara rata-rata memiliki indeks keuangan inklusi yang rendah. Penelitian ini menggunakan data-data dari lembaga keuangan konvensional. Metode yang digunakan adalah dengan menghitung aksesibilitas dan ketersediaan serta penggunaan lembaga keuangan formal konvensional di provinsi tersebut. Menurut Sanjaya dan Nursechafia (Nursechafia 2016) faktor-faktor yang berpengaruh terhadap indeks keuangan inklusif adalah jumlah orang miskin, jumlah orang miskin yang bekerja, jumlah kantor bank, jumlah orang dewasa, jumlah keluarga miskin yang menerima pembiayaan, dan jumlah keluarga miskin. Faktor-faktor tersebut juga berpengaruh terhadap inklusifitas bank syariah.

Untuk bank syariah, selain faktor di atas juga diperlukan pengenalan untuk mengentaskan kebutaan mengenai bank syariah yang dialami masyarakat luar Jawa pada umumnya. Bank syariah perlu untuk memperluas kantor cabang, khususnya di daerah luar Jawa dan kota-kota kecil di pulau Jawa. Selain itu, menurut Muhammad, bank syariah juga perlu untuk meningkatkan kualitas aktiva melalui restrukturisasi pembiayaan, memperkuat basis permodalan, memiliki strategi usaha yang fokus dengan suatu kompetensi yang terpusat sebagai daya saing, dan yang terakhir memperkuat basis sistem operasional untuk memperluas sistem distribusi penyaluran pembiayaan (Muhammad 2002).

\section{Simpulan}

Berdasarkan hasil analisis faktor menunjukkan bahwa faktor yang terkait dengan Bank Umum Syariah (BUS) dan Unit Usaha Syariah (UUS) adalah faktor dominan atau faktor yang paling berkontribusi dalam pengukuran financial inclusion perbankan syariah pada sektor pertanian di Indonesia. Berdasarkan kontribusi terhadap angka indeks keuangan inklusif di Indonesia provinsi yang paling mendominasi adalah provinsi Jawa Barat. Oleh karena itu perlu upaya untuk meningkatkan kontribusi masing-masing

Economica: Jurnal Ekonomi Islam - Volume 8, Nomor 1 (2017) 
Bank Syariah dan Unit Usaha Syariah di daerah Indonesia Timur, khususnya NTT, Papua Barat dan Papua.

BPRS juga diharapkan mampu memberikan kontribusi lebih kepada sektor pertanian di daerah-daerah karena secara peluang dan lokasi kantor lebih dekat kepada petani daerah daripada Bank Umum Syariah dan Unit Usaha Syariah.

\section{Daftar Pustaka}

Ahmet Faruk Aysan, Muhammed Habib Dolgun \& M. Ibrahim Turhan. 2013. "Assessment of the Participation Banks and Their Role in Financial Inclusion in Turkey." Emerging Markets Finance \& Trade 49, 99-111.

BPS, Badan Pusat Statistik. 2016. Jumlah Penduduk Miskin Menurut Provinsi (Number of Poor People by Province). Jakarta: Badan Pusat Statistik.

Fara Farida, H. Siregar, Nunung Nuryartono \& Eureka Intan. 2015. "Micro enterprises' access to people business credit program in Indonesia: Credit rationed or non-credit rationed?" International Journal of Economic Perspectives 9, no. 2, Juni, 57-70.

Farihah, H. Daroini \& U. 2015. Disparitas Financial Inclusion Perbankan Syariah pada Subsektor UMKM. Malang: Otoritas Jasa Keuangan.

Indonesia, Bank. 2014. Booklet Keuangan Inklusif. Jakarta: Bank Indonesia.

Jatim, Bappeprov. 2011. Analisa Pengeluaran Publik Jawa Timur 2011. Jakarta: Bank Dunia.

Kim, Jong-Hee. 2016. "A Study on the Effect of Financial Inclusion on the Relationship Between Income Inequality and Economic Growth." Emerging Markets Finance \& Trade 52, no. 2, 498-512.

Lia Nazliana Nasution, Pipit Buana Sari, Handriyani Dwilita. 2013. "Determinan Keuangan Inklusif Di Sumatera Utara, Indonesia." Jurnal Ekonomi dan Studi Pembangunan 14, no. 1, April, 58-66.

Muhammad. 2002. Manajemen Bank Syariah. Yogyakarta: AMP YKPN.

Nursechafia, I Made Sanjaya. 2016. "Inklusi Keuangan dan Pertumbuhan Inkusif: Analisis Antar Provinsi di Indonesia. Buletin Ekonomi Moneter dan Perbankan." 18, no. 3, Januari, 282-306. 
OJK, Otoritas Jasa Keuangan. 2016. Statistik Perbankan Syariah. Vol. Agustus. Jakarta.

Öztürkkal, Nurhan Davutyan \& Belma. 2016. "Determinants of SavingBorrowing Decisions and Financial Inclusion in a High Middle Income Country: The Turkish Case." Emerging Markets Finance \& Trade 52, no. 11, 2512-2529.

Sarma, Mandira. 2012. "Index of Financial Inclusion - A measure of financial sector inclusiveness." Berlin Working Papers on Money, Finance, Trade and Development 7.

Sethy, Susanta Kumar. 2016. "Developing a Financial Inclusion Index and Inclusive Growth in India." Theoretical and Applied Economics XXIII, no. 2, 187-206.

Siregar, Mulya. 2002. "Agenda Pengembangan Perbankan Syariah Untuk Mendukung Sistem Ekonomi Yang Sehat di Indonesia: Evaluasi, Prospek dan Arah Kebijakan." IQTISAD Journal of Islamic Economics 3, no. 1, Maret, 46-66.

Sneha, P. Hima Bindu \& Jain V. 2011. "Role of Infrastructure in Financial Inclusion In Remote Villages Of Medak District In Andhra Pradesh." Asia Pacific Journal of Research in Business Management 2, no. 7, Juli, 1-1.

Tambunan, T. 2007. "Importance of Agricultural Growth for Poverty Reduction: The Indonesian Case." Asia-Pacific Journal of Rural Development 17, no. 2,1-26 